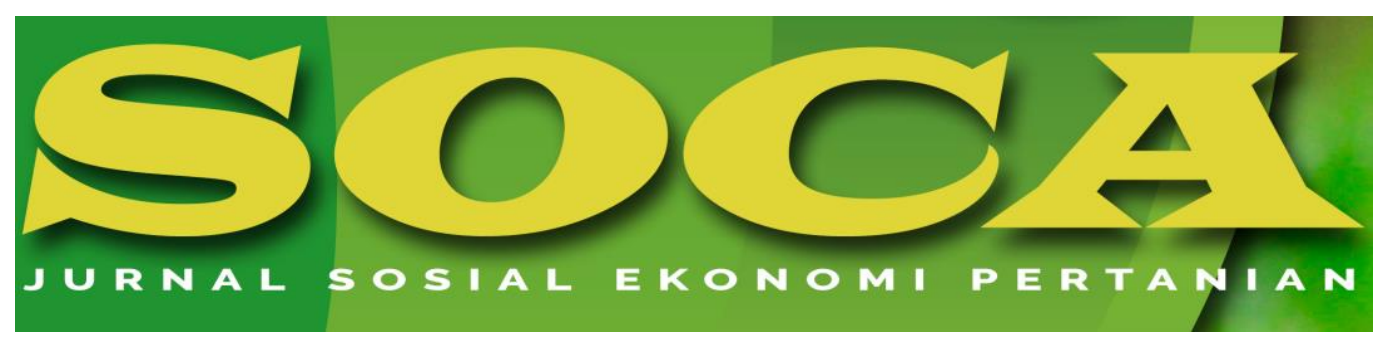

https://ojs.unud.ac.id/index.php/soca

\title{
Motivation Of Dryland Utilization On Integrated Farming In East Lombok
}

\author{
Pande Komang Suparyana , Aeko Fria Utama FR ${ }^{2}$ and Putu Eka Pasmidi Ariati ${ }^{3}$ \\ ${ }_{1,2}$ Agribusiness Department, Agriculture Faculty, Mataram University, West Nusa Tenggara \\ ${ }^{3}$ Agrotechnology Department, Agriculture Faculty, Mahasaraswati Denpasar University, Bali \\ Email:pande.suparyana@unram.ac.id 1, aekomarya40@gmail.com² and \\ ekapasmidi@gmail.com ${ }^{3}$ \\ Mobile: 0818055553511,0877417167312 and 0819991318583
}

Submitted : 7 April 2020; Revised : 16 April 2020 ; Accepted: 27 April 2020

\begin{tabular}{l}
\hline Keywords: \\
farmer's \\
motivation; \\
integration of \\
farming; \\
livestock \\
\hline
\end{tabular}

\begin{abstract}
Utilization of the dryland farming resources through the integration of the farming and livestock is an alternative to improve the farmer income. This study aimed to analyze the effect of variables on the utilization of the dryland and analyze the effect of those variables on the farmer's motivation in conducting the integration of farming and livestock simultaneously and partially in Gunung Malang Village, Pringgabaya District. There were 82 farmers from 11 farmer institutional group in Gunung Malang Village, Pringgabaya District, East Lombok Regency involved in this study. This study was employed a multiple regression analysis to processed the data. Results showed that the livestock, value-added to the livestock, land-area, farming experience, education level, and the number of the family member variable simultaneously affected the farmer motivation in implementing the farming and livestock integration in Gunung Malang Village. While the livestock capital, farming experience, and the number of the family member variable partially affected the farmer motivation in implementing the farming and livestock integration. The land-area and educational level didn't contribute significantly to the implementation of farming and livestock integration in Gunung Malang Village.
\end{abstract}

How to Cite (APA 6th Style):

Suparyana, P. K., FR, A. F. U., \& Ariati, P. E. P. (2020). Motivation Of Dryland Utilization On Integrated Farming In East Lombok. SOCA: Jurnal Sosial Ekonomi Pertanian, 14(2), 351-361.

https://doi.org/https://doi.org/10.24843/SOCA.2020.v14.i02.p14 


\section{INTRODUCTION}

Dryland farming is an agricultural activity in the dryland area. Some plants such as a staple plant or plant for the fodder could be cultivated on the dry land. The post-harvesting waste like paddy straw, corn stalks, peanut straw, soy straw, and banana stems could be utilized as the fodder (especially for cattle and goat). The livestock's feces also could be processed as organic fertilizers. These facts indicated that the combination of farming and livestock could help in decreasing agricultural costs. This integration between the farming and the livestock system named as an integrated farming system.

Motivation could be defined as an encouragement from the inner self or the external environment in conducting a series of activities to reach particular goals (Widiyanti et al., 2016). Farmer's motivation in implementing innovation on their agricultural activities was a will that able to drive the farmer in conducting an innovation for their group. The innovation could be in the form of integration of farming and livestock activity that could improve the agricultural productivity and farmer income. Some factors such as motive, hope, and the incentive would determine the power of a motivation (Atkinson et al., 1967). The main reason for the farmer in implementing the integration of farming and livestock activity was obtaining a better commodity outcome (quality and quantity). Their hope would add more value to their belief in obtaining better commodity production. The value-added in the form of compensation (higher income) was also adding more power to their motivation.

West Nusa Tenggara was a province in Indonesia with the largest dryland area which covered $84 \%(1,807,463 \mathrm{ha})$ from the total land area. Dryland was highly potential to be developed as a cultivating area with high-price agricultural commodity and required good water management to assure the land productivity. The dryland in East Lombok was spread in some districts, one of them is in Pringgabaya District.

Pringgabaya District has a large dryland area and developing superioragricultural commodity. The utilization of the dryland was accompanied by the use of a water well pump in managing the irrigation management. Some farmers were also combining the cultivation activities with the livestock activities. Gunung Malang village was the largest area in the Pringgabaya District (Institute of National Statistics, 2018). The comparative advantage in conducting agricultural activities in this area was a high potential dryland area and good water resources (rainwater and water ground). Unfortunately, these resources couldn't properly utilized by the farmer. The farmer couldn't use these resources for cultivating plants, conducting livestock activities, or combining both activities. These conditions affected their commodity volume production and income. The main income still came from the selling of the staple food commodity. The decreasing size of the land area and the low land productivity would highly contributed to the low farmer income. Rasahan (2000) stated that the low farmer income could be affected by some factors: 1) small size of the cultivating area for each farmer (with the average of $0.50 \mathrm{ha}$ ), 2) the intensity in cultivating but rarely preserving the land, 3) low commodity prices in national harvesting period.

The farmer's motivation factor in integrating the farming and livestock need to be analyzed to improve the farmer's motivation. The factor affected the farmer's motivation on combining the farming and livestock in Gunung Salak Village was never been conducted. This study aimed to analyze the effect of variables on the utilization of the dryland and analyze the effect of those variables on the farmer's 
motivation in conducting the integration of farming and livestock simultaneously and partially in Gunung Malang Village, Pringgabaya District.

\section{RESEARCH METHODS}

\section{Location and Study Duration}

This study was conducted in Gunung Malang Village, Pringgabaya District, East Lombok Timur Regency from October to December 2019. Gunung Malang Village was chosen as the study location due to several considerations: (1) Gunung Malang Village was the village with the largest area in Pringgabaya District (National Institute of Statistic, 2018), (2) Gunung Village was a village in Pringgabaya which using dry land for their agricultural activity.

\section{Participant Selection Method}

The study population could be defined as the total of subjects or objects with particular criteria set by the researcher to obtain the study finding (Sujarweni, 2015). Based on that definition, there 453 farmers from the 11 farmer institutional group in Gunung Malang Village participated as the study population. The participants were chosen by the accidental sampling technique, a method of participant selection done by choosing participants who have met the researcher accidentally. According to this sampling technique, there were 82 farmers in Gunung Malang Village employed as the study participants.

\section{Data Analysis Method}

This was a descriptive study with a qualitative approach. The qualitative approach was used in analyzing the farmer's motivation in integrating the agricultural and livestock activities. The 18th version SPSS employed to analyze the study data.

Multiple linear regression was used to analyze the study variables. The dependent variable was the farmer motivation in implementing the farming and livestock integration, while the dependent variables consisted of livestock capital, the value-added on the livestock, land area, farming experience, education level, and the number of the family's member. Suharsimi (2013) stated that the formula of $\mathrm{Y}=$ $b_{0}+b_{1} X_{1}+b_{2} X_{2}+\ldots+b_{n} X_{n}$ could be used in the data analysis. That formula could be translated into:

Where:

$$
\mathrm{Y}=b_{0}+b_{1} X_{1}+b_{2} X_{2}+b_{3} X_{3}+b_{4} X_{4}+b_{5} X_{5}+b_{6} X_{6}
$$

$\mathrm{Y} \quad=$ farmer motivation in implementing the of farming and livestock integration

$\mathrm{b}_{0} \quad=$ constanta

$b_{1}-b_{6}=$ regression coefficient on the each variable

$\mathrm{X}_{1} \quad=$ livestock capital

$\mathrm{X}_{2}=$ the value-added on the livestock

$\mathrm{X}_{3}=$ land area

$\mathrm{X}_{4} \quad=$ farming experience

$\mathrm{X}_{5} \quad=$ education level

$\mathrm{X}_{6}=$ the number of the family's member 


\section{Simultaneous Regression Coefficient Test (F-Test)}

F-test was used to know the significance parameter value on the independent variable simultaneously. Therefore the value of the independent variable could be determined to be statistically accepted by comparing its value with the F-values.

\section{Partial Regression Coefficient Test (T-Test)}

T-test was used to know the effect of the independent variable on the dependent variable. This was a hypothesis test on the regression coefficient by comparing the statistical values of each regression coefficient with an at-table value based on the significance level

\section{RESULTS AND DISCUSSION}

\section{The Equation Model on Motivation of Dryland Utilization through Farming and Livestock Integration}

The multiple regression analysis was applied to know the amount of independent variable effect on the dependent variable in a regression model. The regression model used in this study was shown in Table 1.

According to the literatures based approach, the independent variables chosen were livestock capital, value-added on the livestock, land-area, farming experience, education level, and the number of the family member. The correlation between the dependent variable $(\mathrm{Y})$ and the independent variable (Xi) transformed into this equation:

$$
\begin{aligned}
\mathrm{Y}= & b_{0}+b_{1} X_{1}+b_{2} X_{2}+b_{3} X_{3}+b_{4} X_{4}+b_{5} X_{5}+b_{6} X_{6} \\
\mathrm{Y}= & 3.512-2.854 \times 10^{-8} X_{1}+2.175 \times 10^{-8} X_{2}-0.001 X_{3}+0.009 X_{4}+0.021 X_{5}+ \\
& 0.095 X_{6}
\end{aligned}
$$

\begin{tabular}{|c|c|c|c|c|c|c|}
\hline & \multirow[t]{2}{*}{ Model } & \multicolumn{2}{|c|}{$\begin{array}{l}\text { Unstandardized } \\
\text { Coefficients }\end{array}$} & \multirow{2}{*}{$\begin{array}{c}\text { Standardized } \\
\text { Coefficients }\end{array}$} & \multirow[t]{2}{*}{$\mathbf{t}$} & \multirow[t]{2}{*}{ Sig. } \\
\hline & & B & Std. Error & & & \\
\hline \multirow[t]{7}{*}{1} & (Constant) & 3.512 & .125 & & 28.023 & .000 \\
\hline & $\mathrm{X} 1$ & $-2.854 \mathrm{E}-8$ & .000 & -.582 & -6.555 & .000 \\
\hline & $\mathrm{X} 2$ & $2.175 \mathrm{E}-8$ & .000 & .417 & 4.673 & .000 \\
\hline & X3 & -.001 & .001 & -.081 & -.982 & .329 \\
\hline & $\mathrm{X} 4$ & .009 & .003 & .225 & 2.866 & .005 \\
\hline & $\mathrm{X} 5$ & .021 & .023 & .062 & .907 & .367 \\
\hline & $\mathrm{X} 6$ & .095 & .023 & .338 & 4.192 & .000 \\
\hline
\end{tabular}

Table 1. Multiple Linear Regression Equation Model on the Dryland Utilization through Farming and Livestock Integration in Gunung Malang Village (2019)

Dependent Variable : Y

Source : Primary Data (Processed), 2019

The good regression analysis must contain econometric criteria examined by the classic linear model assumptions tests (normality test, heteroscedasticity test, and multicollinearity test). The normality test in the regression model was done to know the data distribution. The normality test in Table 2 showed that the skewness 
ratio was divided with the error standard value of 1.083 . While the value of the Kurtosis ratio was -1.130 (between -2 and +2 ). These values indicated that the linear regression model is ideal in predicting the farmer motivation based on the independent variables used. The dependent variables were also distributed in the normal range. The heteroskedasticity in Table 3 showed that all the independent variable's t-statistical values were not statistically significant, therefore it was assumed that there was no heteroscedasticity problem on this model. According to Table 4 , the VIF value was $<10$, which showed that there was no multicollinearity on the data.

Table 2. Skewness and Kurtosis Test Equation Model on the Dryland Utilization through Farming and Livestock Integration in Gunung Malang Village (2019)

\begin{tabular}{|c|c|c|c|c|c|}
\hline & \multirow{2}{*}{$\begin{array}{c}\mathbf{N} \\
\text { Statistic }\end{array}$} & \multicolumn{2}{|c|}{ Skewness } & \multicolumn{2}{|c|}{ Kurtosis } \\
\hline & & Statistic & $\begin{array}{l}\text { Std. } \\
\text { Error }\end{array}$ & Statistic & Std. Error \\
\hline $\begin{array}{l}\text { Unstandardized } \\
\text { Residual }\end{array}$ & 82 & .288 & .266 & -.594 & .526 \\
\hline Valid N (listwise) & 82 & & & & \\
\hline
\end{tabular}

Source : Primary Data (Processed), 2019

Table 3. Glejser Test Model Equation on the Dryland Utilization through Farming and Livestock Integration in Gunung Malang Village (2019)

\begin{tabular}{|c|c|c|c|c|c|c|}
\hline & \multirow{2}{*}{ Model } & \multicolumn{2}{|c|}{$\begin{array}{l}\text { Unstandardized } \\
\text { Coefficients }\end{array}$} & \multirow{2}{*}{$\begin{array}{c}\begin{array}{c}\text { Standardized } \\
\text { Coefficients }\end{array} \\
\text { Beta }\end{array}$} & \multirow{2}{*}{$\mathbf{t}$} & \multirow{2}{*}{ Sig. } \\
\hline & & B & Std. Error & & & \\
\hline \multirow[t]{7}{*}{1} & (Constant) & .223 & .066 & & 3.407 & .001 \\
\hline & $\mathrm{X} 1$ & $-1.532 \mathrm{E}-10$ & .000 & -.010 & -.067 & .947 \\
\hline & $\mathrm{X} 2$ & $-2.897 \mathrm{E}-9$ & .000 & -.180 & -1.189 & .238 \\
\hline & X3 & .000 & .000 & -.130 & -.931 & .355 \\
\hline & $\mathrm{X} 4$ & .001 & .002 & .064 & .486 & .629 \\
\hline & $\mathrm{X} 5$ & .010 & .012 & .098 & .845 & .401 \\
\hline & $\mathrm{X} 6$ & -.009 & .012 & -.102 & -.746 & .458 \\
\hline & & oresid & & & & \\
\hline
\end{tabular}


Table 4.VIF Test Model Equation on the Dryland Utilization through Farming and Livestock Integration in Gunung Malang Village (2019)

\begin{tabular}{|c|c|c|c|c|c|}
\hline \multirow{2}{*}{\multicolumn{2}{|c|}{ Model }} & \multirow[t]{2}{*}{$\mathbf{t}$} & \multirow[t]{2}{*}{ Sig. } & \multicolumn{2}{|c|}{ Collinearity Statistics } \\
\hline & & & & Tolerance & VIF \\
\hline & (Constant) & 28.023 & .000 & & \\
\hline & $\mathrm{X} 1$ & -6.555 & .000 & .527 & 1.899 \\
\hline & $\mathrm{X} 2$ & 4.673 & .000 & .522 & 1.915 \\
\hline & X3 & -.982 & .329 & .615 & 1.626 \\
\hline & $\mathrm{X} 4$ & 2.866 & .005 & .676 & 1.480 \\
\hline & $\mathrm{X} 5$ & .907 & .367 & .880 & 1.137 \\
\hline & $\mathrm{X} 6$ & 4.192 & .000 & .638 & 1.567 \\
\hline & ne & & & & \\
\hline & urce & Primary I & rocessed & 19 & \\
\hline
\end{tabular}

According to Table 5, the Adjusted $\mathrm{R}^{2}$ value was 0.663 or $66.3 \%$. This result showed that $66.3 \%$ farmer motivation in implementing farming and livestock integration in Gunung Malang Village affected by the livestock capital, value-added on the livestock, land-area, farming experience, education level, and the number of the family member variable. The rest of the adjusted $r^{2}$ value was 0.337 or $33.7 \%$ which showed that the farmer motivation was affected by other factors. The rest of the adjusted $r^{2}$ value was less than $50 \%$ that indicated the independent variables employed in this study were adequate in predicting the dependent variable outcome. The R-value was 0.830 which informed that there was a strong correlation between the farmer motivation and those six dependent variables.

Table 5. The Summary Model Equation on the Dryland Utilization through Farming and Livestock Integration in Gunung Malang Village (2019)

\begin{tabular}{lcccr}
\hline Model & R & R Square & Adjusted R Square & \multicolumn{2}{c}{$\begin{array}{c}\text { Std. Error of the } \\
\text { Estimate }\end{array}$} \\
\hline 1 & $.830^{\mathrm{a}}$ & .688 & .663 & .20980 \\
\hline $\begin{array}{l}\text { Dependent Variable: Y } \\
\text { a. Predictors: (Constant), X6, X3, X5, X1, X4, X2 }\end{array}$ & & \\
Source : Primary Data (Processed), 2019 & &
\end{tabular}

\section{The Simultaneous Effect of the Independent Variables on the Dryland Utilization Motivation through the Farming and Livestock Integration}

F-Test is a test done to know the simultaneous effect of the variable of livestock capital (X1), value-added on the livestock (X2), land-area (X3), farmingexperience (X4), level of education (X5), and the number of family member (X6) on the farmer's motivation in the implementation farming and livestock integration. 
Table 6. The ANOVA Model Equation on the Dryland Utilization through Farming and Livestock Integration in Gunung Malang Village (2019)

\begin{tabular}{|c|c|c|c|c|c|}
\hline Model & Sum of Squares & df & Mean Square & $\mathbf{F}$ & Sig. \\
\hline 1 Regression & 7.290 & 6 & 1.215 & 27.604 & $.000^{a}$ \\
\hline Residual & 3.301 & 75 & .044 & & \\
\hline Total & 10.591 & 81 & & & \\
\hline \multicolumn{6}{|c|}{ Dependent Variable : Y } \\
\hline Predictors & : (Constant), X6, & $3, x 5$, & $\mathrm{X} 1, \mathrm{X} 4, \mathrm{X} 2$ & & \\
\hline
\end{tabular}

According to the Table 6 , the F-value was $0.000(<0.05)$. This result indicated that the variable of livestock capital (X1), value-added on the livestock (X2), landarea (X3), farming-experience (X4), level of education (X5), and the number of family member (X6) simultaneously affected the dependent variable (farmer's motivation) on the farming and livestock integration (Y).

\section{The Partial Effect of the Independent Variables on the Dryland Utilization Motivation through the Farming and Livestock Integration}

T-test is a test done to know the partial effect of the independent variable: livestock capital (X1), value-added on the livestock (X2), land-area (X3), farmingexperience (X4), education-level (X5), and the number of family member (X6) on the farmer motivation in implementing farming and livestock integration $(\mathrm{Y})$.

Table 1 showed the significance value of the capital-livestock was 0.000 $(<0.05)$. This result indicated that the livestock capital was significantly affected the farmer motivation in implementing the farming and livestock integration $(\mathrm{Y})$ on $\mathrm{a}=$ $5 \%$. The capital livestock coefficient value was negative which signified that higher livestock capital would produce lower farmer motivation. The capital livestock variable $\left(\mathrm{X}_{1}\right)$ partially affected the farmer motivation in implementing the farming and livestock integration (Y). A study done by Nisa and Zain (2015) found that capital would majorly affected the farmer motivation. Capital is a power that able to determine the pace of innovation to be implemented by the farmer (Mardikanto, 1993). The availability of capital is a supporting factor in implementing the farming and livestock integration.

Table 1 also showed that the value-added on livestock significance value was $0.000(<0.05)$. This result indicated that the value-added to the livestock variable significantly affected the farmer motivation in implementing farming and livestock integration $(\mathrm{Y})$ on $\mathrm{a}=5 \%$. The coefficient value on this variable was positive which showed that the higher value-added to the livestock variable produced higher farmer motivation. The study was done by Apriliana and Mustadjab (2016) and Theresia et al. (2016) showed that the farmer's income and the commodity selling price are the factors which able to interfere with the farmer decision in cultivating particular commodity. This result was parallel with the result of this study. The value-added in livestock variable (X2) partially affected the farmer motivation in farming and livestock integration (Y). The waste on the farming field could be processed as the fodder for the livestock. The utilization of this waste would decrease the cost for livestock activities which could increase the farmer income in the end. 
The significance value of the land-area variable $\left(\mathrm{X}_{3}\right)$ was $0.329(>0.05)$. This result indicated that the land-area variable didn't significantly affect the farmer motivation in the implementation of the farming and livestock integration $(\mathrm{Y})$ on the $a=5 \%$. This result indicated that the land-area used didn't affect the farmer motivation in the implementation of the farming and livestock integration. Result from a study done by Adegoun et al. (2008), Hendarto et al. (2012), Afriani et al. (2014), Kadar et al. (2016), Anisah \& Hayati (2017), and Wijaya et al. (2019) were parallel with the result in this study. These studies found that the land-area used didn't affected the farmer motivation. The size of the land-area used were provided the same level of income. The livestock growth also only affected by the availability of the fodder, it didn't depend on the land area used by the farmer.

Table 1 showed the farming experience (X4) significance value was 0.005 $(<0.05)$. This result showed that the farming experience partially and significantly affected farmer motivation in implementing the farming and livestock integration $(\mathrm{Y})$. The coefficient value was positive which indicated that the longer farming experience produced higher farmer motivation. Results from a study done by the Afriani et al. (2014), Sudarko and Rdjal (2016), Anisah and Hayati (2017), and Wijaya et al. (2019) was parallel with the result of the study. Experience could be defined as knowledge in a certain amount of time from the learning process (Padmowihardjo, 1994). The longer farming experience contributed to the higher level of farming knowledge. This knowledge would majorly contributed to their agricultural planning in obtaining higher income. Farmer with longer farming experience able to take better agricultural decisions. They tend to have more skill, competencies, and innovation compare with the farmer with shorter farming experience (Becot et al., 2014). From those experiences, they also able to asses proper visibility of the farming and livestock integration. The farming and livestock integration providing a chance of no agricultural waste. The plant waste could be used as the fodder, while the livestock waste could be used as the fertilizer.

The education level significance value (X5) was $0,367(>0,05)$. This result indicated that the education value didn't significantly affected the farmer motivation in implementing farming and livestock integration (Y). Therefore, the Ho was accepted and Ha was refused. This result indicated that the level of education didn't affect the farmer motivation in implementing farming and livestock integration. A similar result was found in the study done by Nisa and Zain (2015), Kadar et al. (2016), Widiyanti et al. (2016), Harmoko (2017), Anisah and Hayati (2017), and Saputra et al. (2017). The formal education level didn't affect the farmer's motivation in implementing farming and livestock integration, but informal education was stated able to increasing the farmer knowledge.

Table 1 showed that the significance value of the number of the family member was $0.000(<0.05)$. This result showed that the number of family member variables significantly affected the farmer motivation in implementing the farming and livestock integration $(\mathrm{Y})$. The coefficient value was positive which indicated that the higher number of the family member contributed to the higher farmer motivation in implementing the farming and livestock integration. A study done by Sudarko and Rdjal (2016) and Wijaya et al. (2019) showed parallel results with this study. Farmers with a higher number of family members tended to be more motivated because they have to make more income to meet all their family member's needs (Gohong, 1993). The higher number of family member would increase their living cost. The 
implementation of the farming and livestock integration would help the farmer to gain more income for meeting their family need.

\section{CONCLUSION}

The farmer's motivation in integrating the farming and livestock in Gunung Malang Village was significantly and simultaneously affected by the independent variables: livestock capital, the value-added on the livestock, land area, farming experience, education level, and the number of the family's member. The livestock capital, the value-added on the livestock, the number of the family's members, and the farming experience variable partially contributed to the farmer motivation in implementing the farming and livestock activity integration in Gunung Malang Village. While the land area and education level variables didn't significantly contributed to the farmer motivation in implementing the farming and livestock activity.

\section{RECOMMENDATION}

The farmer motivation in farming and livestock activity integration in Gunung Malang village was contributed to the farmer's higher income. It was represented by the higher value-added on their agricultural activity and the improvement of family member numbers who have supported the farmer in implementing the farming and livestock integration. However, the increased livestock capital would decrease farmer motivation because it is able in decreasing the income. Therefore, the local stakeholders and national government parties should be providing livestock capital to improve and maintain the farmer motivation in implementing the farming and livestock integration in Gunung Malang Village.

The farming experience also significantly contributed to the farmer motivation in implementing the farming and livestock integration. Consequently, agricultural extentions is urgently required to be conducted to improve the farmer's knowledge and motivation in implementing the farming and livestock integration.

\section{REFERENCES}

Adegoun, O. A., Ajana, A. M., \& Ayinla, O. A. (2008). Application Of Logit Model In Adoption Decision: A Study Of Hybrid Clarias In Lagos State, Nigeria. American Eurasian Journal Of Agricultural And Environmental Sciences, 4(4), 468-472. https://www.sid.ir/en/journal/ViewPaper.aspx?ID=300373

Afriani, H., Nahri Idris, \& Fatati F. (2014). Minat Dan Motivasi Peternak Untuk Mengembangkan Ternak Sapi Pada Kawasan Perkebunan Kelapa Sawit Di Propinsi Jambi. Jurnal Ilmiah Ilmu-Ilmu Peternakan Universitas Jambi, XVII(2), 77-83. https://doi.org/10.22437/jiiip.v17i2.2308

Anisah, A., \& Hayati, M. (2017). Pengambilan Keputusan Petani untuk Tetap Berusahatani Cabe Jamu di Kecamatan Bluto, Sumenep. AGRARIS: Journal of Agribusiness and Rural Development Research, 3(2), 112-118. https://doi.org/10.18196/agr.3251 
Apriliana, M., \& Mustadjab, M. (2016). Analisis Faktor-Faktor yang Mempengaruhi Pengambilan Keputusan Petani Dalam Menggunakan Benih Hibrida Pada Usahatani Jagung (Studi Kasus di Desa Patokpicis, Kecamatan Wajak, Kabupaten Malang). HABITAT, 27(1), 7-13. https://doi.org/10.21776/ub.habitat.2016.027.1.2

Atkinson, J., Cofer, C., \& Appley, M. (1967). An Introduction to Motivation. The American Journal of Psychology. https://doi.org/10.2307/1421000

Becot, F. A., Conner, D. S., Kolodinsky, J. M., \& Méndez, V. E. (2014). Measuring the Costs of Production and Pricing on Diversified Farms: Juggling Decisions Amidst Uncertainties. Journal of ASFMRA, 174-191. https://doi.org/10.2307/jasfmra.2014.174

BPS. (2018). Kecamatan Pringgabaya Dalam Angka 2018. BPS. https://lomboktimurkab.bps.go.id/publication/2018/09/26/03eb5fb84782 a8a6c243d5ee/kecamatan-pringgabaya-dalam-angka-2018.html

Gohong, G. (1993). Tingkat Pendapatan dan Tingkat Kesejahteraan Petani serta Faktor-faktor yang Mempengaruhinya pada Daerah Opsus Simpei Karuhei di Kabupaten Kapuas Propinsi Kalimantan Tengah. IPB (Bogor Agricultural University). https://repository.ipb.ac.id/handle/123456789/21139?show=full

Harmoko. (2017). Tingkat Motivasi Petani Dalam Beternak Sapi Di Kecamatan Sambas Kabupaten Sambas. JSEP (Journal of Social and Agricultural Economics), 1O(1), 1. https://doi.org/10.19184/jsep.v10i1.5217

Hendarto, Badrudin, R., \& Yuliarso, M. Z. (2012). Faktor-Faktor Yang Berhubungan Dengan Tingkat Motivasi Petani Sawit Dalam Pengembalian Kredit Di Koperasi Baitul Maal Watamwil Desa Srikaton Kecamatan Pondok Kelapa Kabupaten Bengkulu Tengah. Jurnal AGRISEP Kajian Masalah Sosial Ekonomi Pertanian Dan Agribisnis, 11(1), 22-34. https://doi.org/10.31186/AGRISEP.11.1.22-34

Kadar, L., Siregar, H., \& Kumala Putri, E. I. (2016). Faktor-Faktor Yang Berpengaruh Terhadap Adopsi Varietas Unggul Jagung Putih Di Kabupaten Grobogan-Jawa $\begin{array}{lll}\text { Tengah. Informatika Pertanian, 25(2), } 215 . & .\end{array}$ https://doi.org/10.21082/ip.v25n2.2016.p215-220

Mardikanto, T. (1993). Penyuluhan Pembangunan Pertanian. Sebelas Maret University Press.

Nisa, N. K., \& Zain, I. M. (2015). Motivasi Petani Dalam Menanam Komoditas Padi Pada Daerah Lumbung Padi Di Kabupaten Gresik. Swara Bhumi, 3(3). https://jurnalmahasiswa.unesa.ac.id/index.php/swarabhumi/article/view/ 12895

Padmowihardjo, S. (1994). Metode Penyuluhan Pertanian. Universitas Terbuka. 
Rasahan, C. (2000). Pertanian dan Pangan. Pustaka Sinar Harapan.

Saputra, G. R., Isyaturriyadhah, I., \& Pitriani, P. (2017). Faktor Sosial Ekonomi Yang Memotivasi Petani Dalam Usahatani Jahe Di Kecamatan Renah Pembarap Kabupaten Merangin. JAS (Jurnal Agri Sains), 1(2). https://doi.org/10.36355/jas.v1i2.139

Sudarko, S., \& Rdjal, J. A. (2016). Peningkatan Motivasi Petani Kopi Rakyat Dalam Diversifikasi Pengolahan Produk Primer Dan Sekunder Kopi Dengan Pendekatan Agribisnis Di Kabupaten Jember. Agritrop: Jurnal Ilmu-Ilmu Pertanian (Journal of Agricultural Science), 14(2). https://doi.org/10.32528/AGR.V14I2.433

Suharsimi, A. (2013). Prosedur Penelitian: Suatu Pendekatan Praktik (Edisi Revisi). Jakarta: Rineka Cipta. https://doi.org/10.1017/CBO9781107415324.004

Sujarweni, V. W. (2015). Metodologi Penelitian Bisnis \& Ekonomi. Pustaka Baru Press.

Theresia, V., Fariyanti, A., \& Tinaprilla, N. (2016). Pengambilan Keputusan Petani Terhadap Penggunaan Benih Bawang Merah Lokal dan Impor di Kabupaten Cirebon, Jawa Barat. AGRARIS: Journal of Agribusiness and Rural Development Research, 2(1), 50-60. https://doi.org/10.18196/agr.2125

Widiyanti, N. M. N. Z., Baga, L. M., \& Suwarsinah, H. K. (2016). Kinerja Usahatani dan Motivasi Petani dalam Penerapan Inovasi Varietas Jagung Hibrida padaLahan Kering di Kabupaten Lombok Timur. Jurnal Penyuluhan, 12(1). https://doi.org/10.25015/penyuluhan.v12i1.11317

Wijaya, I. P. E., Suhaeni, S., \& Azkiya, L. N. (2019). Analisis Motivasi Petani Dalam Menanam Kopi Sanggabuana Di Kabupaten Karawang (Studi Kasus Desa Mekarbuana Kecamatan Tegalwaru). MEDIAGRO, 15(01). https://doi.org/10.31942/md.v15i01.3072 